\title{
Coins in Context: Local Economy, Value and Practice on the East African Swahili Coast
}

\author{
Stephanie Wynne-Jones \& Jeffrey Fleisher
}

\begin{abstract}
Coinage occupies an unusual position in archaeological research. Thriving scholarship on numismatics and monetary history ensures that the objects themselves are well-studied, often seen as an indication of chronology and of stylistic and commercial links. Yet coins might also be analysed as artefacts, and explored as part of the symbolic world of material culture through which archaeologists understand meaning and value in past societies. Using a recently-excavated assemblage of medieval Kilwa-type coins from Songo Mnara on the East African Swahili coast, this article explores the multiple ways that value was ascribed and created through use, rejecting a simple dichotomy between substantive and formal value. Attention is given to the contexts of the coins, which enables a discussion of the relationship between power and the constitution of value, the circulation and use of

coins among townspeople, and their use within ritual and commemorative activity.
\end{abstract}

It seems very improbable that [Songo Mnara] was ever a considerable commercial centre; I could find no coin of any kind. (Mathew 1959, 157)

The Rev. Gervase Mathew's assessment of Songo Mnara, an elaborate medieval Swahili town on the southern Tanzanian coast (Fig. 1), reveals much about how East African coins and coinage have been deployed in interpretations of ancient Swahili economies and trade. The association drawn between coinage and commerce also speaks to the role that numismatics has had within archaeology as a discipline. Coins have long served as a proxy for commercial exchanges, with their value and usage determined by the metal they contain, the monetary systems of which they were a part, and their association with particular rulers or regimes. This formalist approach to value and coinage is, however, at odds with the ways that other object categories have been understood. Developments within numismatics, economic anthropology and symbolic archaeologies are bringing consideration of context and value to the fore and allowing dialogue between these different spheres of inquiry. This does not mean movement towards a purely substantivist viewpoint, viewing economic relations as structured differently in 'primi- tive' societies than in the modern market-oriented economy (Dalton 1975; Gregory 1997; Polanyi 1957; 1968). Rather, coin analyses have drawn on insights into the social meanings of exchange, collapsing the distinction between substantivist and formalist approaches and demonstrating the impossibility of dividing between the two, even for a category such as coinage, which seems to embody abstracted value like no other (Thomas 1991, 9-14; Weiner 1992, 23-8). Money is simultaneously alienable and inalienable, as it 'represents a society's untouchable perception of value at one and the same time as it brings that into the marketplace' (Kilger 2008, 262).

Coins with clearly-defined contexts of use have a great potential to speak to these aspects of value in the societies we study through archaeology, and can be a key part of our considerations of material culture. In this article, we examine a new collection of coins from recent excavations in Songo Mnara as an entry point into considering their local value, use and circulation. Songo Mnara is a grand, coral-built Swahili town that dates to the fourteenth-fifteenth centuries $\mathrm{AD}$ (Fig. 2). The site itself occupies an island just off the coast of southern Tanzania, in the same archipelago as the famous trading town of Kilwa Kisiwani (Chit- 


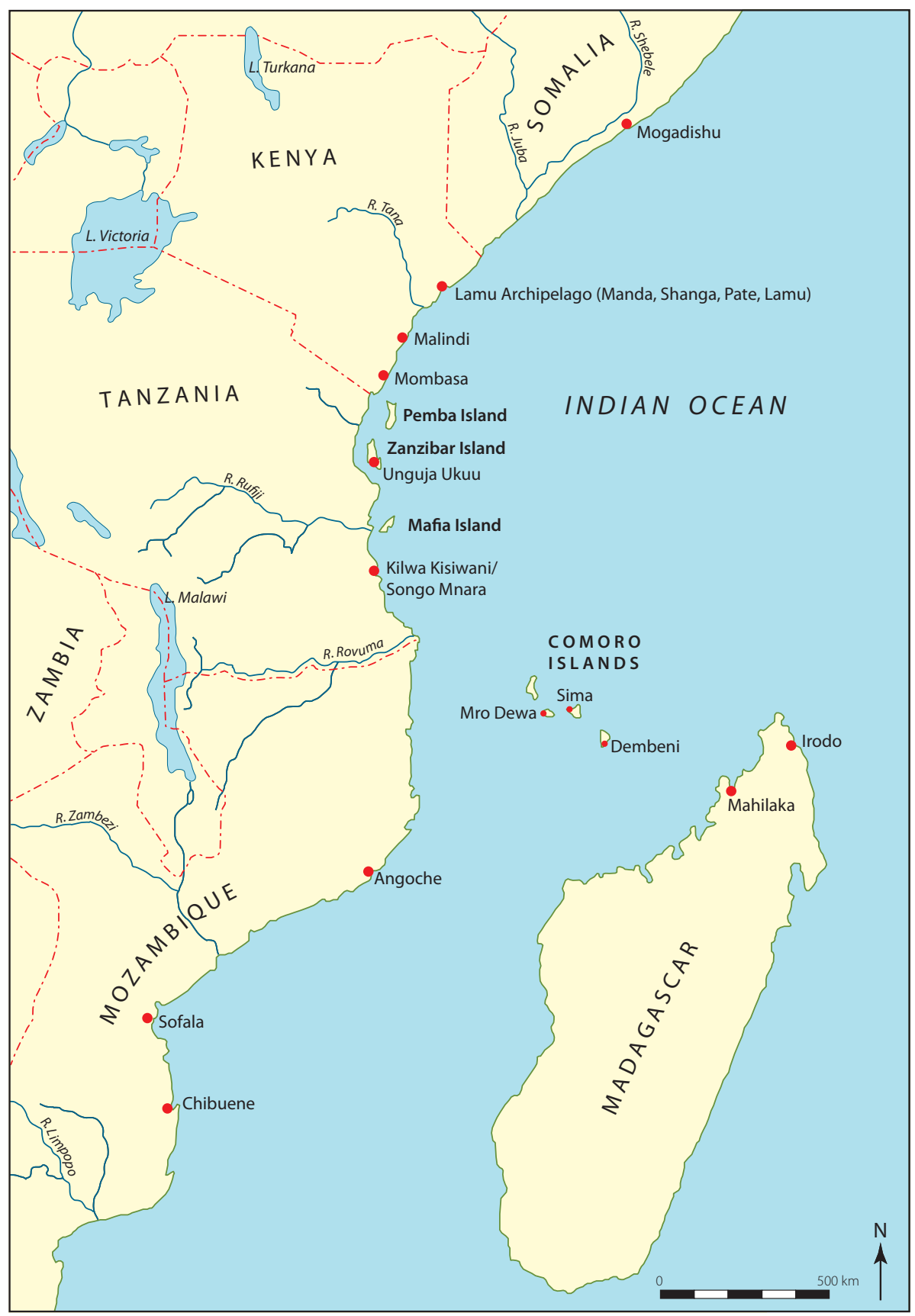

Figure 1. East African Coast showing places mentioned in the text.

tick 1974). Songo Mnara is an enigmatic site, and its relationship to Kilwa Kisiwani is little understood. It has been suggested (Chittick 1961; Mathew 1959; Sutton 1998) that the grand stone town found here was an offshoot of Kilwa, perhaps housing particularly wealthy merchants who wanted some degree of independence from the Kilwa dynasty. If so, we might suppose that the town would have been the focus of international trade, and its grandeur cer- tainly suggests a source of significant wealth. The archaeology of the site, however, reveals little in the way of evidence for imported goods; indeed, the majority of the artefacts are of local manufacture and use (Fleisher \& Wynne-Jones 2010a; Pradines \& Blanchard 2005; Wynne-Jones \& Fleisher 2010). A significant proportion of the urban space is given over to commemorative and ritual architecture, with hundreds of graves and five mosques testifying to 


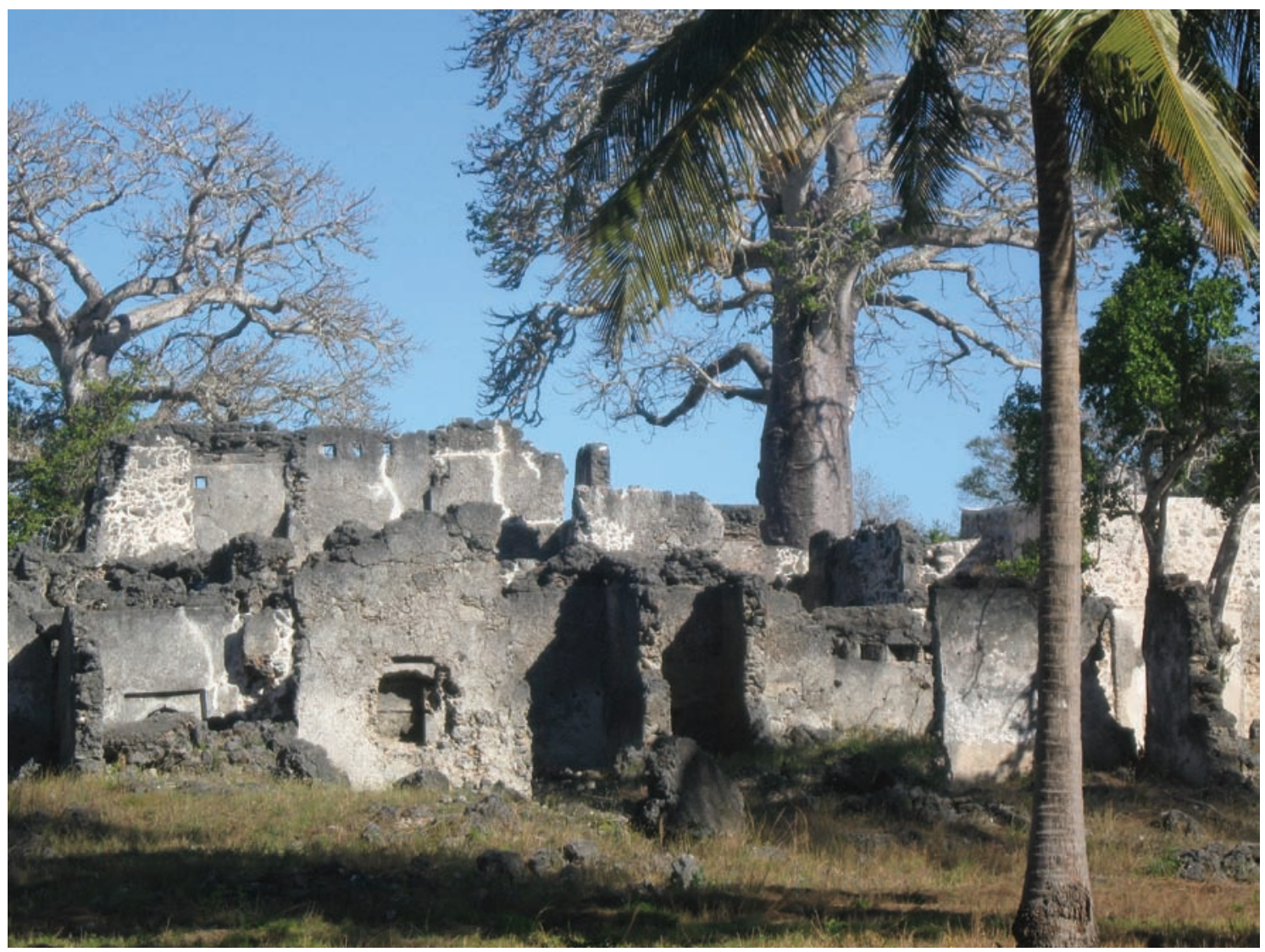

Figure 2. Coral rag architectural ruins at Songo Mnara, Tanzania.

the centrality of Islamic practice in the life of the town (Fig. 3). The overall sense, then, is of a town that is part of the world of Indian Ocean trade, but in which daily life is oriented around local practices and interactions.

Excavations at the site have produced a corpus of 64 coins (Fleisher \& Wynne-Jones 2010b) allowing the first consideration of Swahili coinage from welldefined contexts. These open a route into thinking through coins as archaeological objects, with their value negotiated in and through social situations. The finds from Songo Mnara are firmly linked to particular contexts at the site. Unlike the large-scale excavations at Kilwa Kisiwani itself, Songo Mnara was excavated using broad exposures, and recorded through a single-context recording system. This means that the coin finds are situated within sealed, closely-delineated archaeological deposits which relate to the uses of the structures and contemporary activities in outdoor spaces at the site. Although referencing a wider system of Islamic commerce, we argue that Kilwa coinage represents more than a reproduction of distant values; it was also a system based on local authority and token value, likely used exclusively within southern Swahili towns. Thus, the Songo Mnara evidence not only challenges Mathew's failure to locate coins at the site, but also hints at a rich local usage that moves beyond simply indicating 'considerable commercial' activity.

This discussion focuses on three aspects of the way in which coins operated as symbolic artefacts. First, we explore the implications of Songo Mnara's coinage for our understanding of value. Rather than regarding value as a self-evident feature of coinage - an assumption normally related to the relationship with quantifiable metal specie - we explore the different ways in which these coins were valuable and how that was constituted in Swahili society. The links between value and power are thereby highlighted, and we expand on the ways that the coins derived their worth from particular sultans and associations. Second, value might also have been grounded in the ways that townspeople used and manipulated the coinage; the elite may also have benefited from the actions of non-elite inhabitants, as the latter circulated and found value in their coinage. Symbolic value may therefore have been not only ascribed, but created in the myriad 'tournaments of value' (Appadurai 1986, 21-2) that 


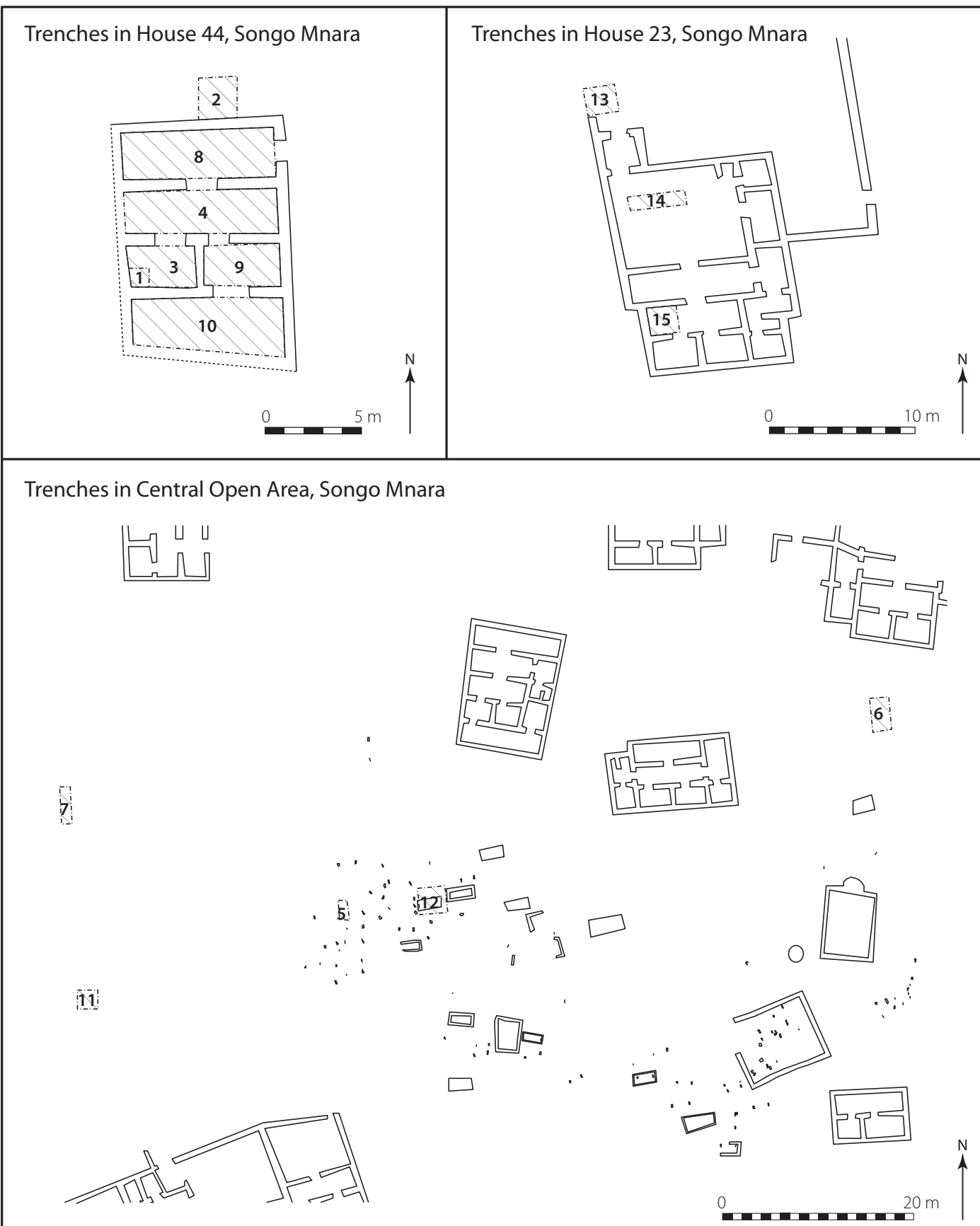

Figure 3. Plan of Songo Mnara showing trench locations: house excavations (above) and open-area excavations (below).

occurred daily as part of the life of the town. Finally, the apparent uses of the coins lead us to a consideration of the ways these objects circulated, apparently in both mundane and ritual spheres, with an active role in practices of commemoration. We argue that all of these aspects of the coinage were interwoven in their function as symbolic objects, and that this is best explored by thinking of coins as artefacts.
One of the great challenges in the archaeology of the East African coast has been to shed colonialera ideas of the Swahili as a 'foreign' society and to explore the autochthonous roots of Swahili towns. Within these shifting paradigms, discussions over Swahili identity are often framed as a negotiation between foreign and local ideas. As Chami (1994) has noted, this either/or framing has more to do with 
colonial/post-colonial ideas about ethnicity than with the nature of past Swahili society. As such, a study of Swahili coins that aims to collapse substantivist/ formalist distinctions will serve to move beyond the debates about 'internal' and 'external' that have structured Swahili scholarship to date.

\section{Coins and the East African coast}

Kilwa coinage, made primarily of copper but with a few examples of gold and silver, was minted locally, marked with the names of sultans, and decorated with rhyming couplets in Arabic script, honorifics that praised Allah and the sultan himself. The analysis of Kilwa coins has been an important part of debates on coastal chronology since they provide some of the only textual evidence for the pre-colonial coast of East Africa, and the interpretation of the various sultans' inscriptions and familial relationships has consequently had a prominent role in the writing of coastal histories (Chittick 1965; 1973; 1974; FreemanGrenville 1957; 1958; Horton \& Middleton 2000; Walker 1936; 1939; Walker \& Freeman-Grenville 1956). However, since the coins do not bear dates, and most coin assemblages come from excavations by arbitrary level as well as unprovenienced hoards and collections, the issue of dating remains problematic (Fleisher \& Wynne-Jones 2010b). Thus, while debate about East African coins looms large in the literature on Swahili towns, there has been little consideration of how coins were actually used, or how their value was conceptualized locally.

Kilwa coins have been found at archaeological sites up and down the East African coast, but their production (and use) seems to have been concentrated primarily in the southern part of the coast, centred on the town of Kilwa Kisiwani. Kilwa was one of the most powerful of the Swahili towns that emerged along the coast from southern Somalia to the Comoro Islands from the tenth century AD. Crucially, Kilwa was linked to the gold trade flowing out of the Zimbabwean plateau, and was able to control both internal and external commercialization of this part of the coast until the sixteenth century. A series of named dynasties that ruled Kilwa is known through the Kilwa Chronicles, a collection of documented oral histories of the town's rulers (Freeman-Grenville 1962). Two dynasties, the Shirazi and Mahdali, ruled at Kilwa from the eleventh to sixteenth centuries and were the most vigorous minters of Swahili coins. Thousands of Kilwa-type coins, mostly of copper, have been found at the main site of Kilwa Kisiwani, but also on the nearby island of Mafia - where towns related to the Kilwa dynasties existed - and now at Songo Mnara. Despite the large numbers of coins produced at Kilwa, only a few have been found at more distant coastal towns. Excavations over many years at Shanga on the northern Kenya coast, for example, produced 64 coins in total, two of which were of Kilwa types (Horton 1996, 368).

Analyses of Kilwa's coins have tended to focus on their historiographical potential, exploring the various issues for hints as to the dynastic succession of Kilwa and as chronological markers. This debate has not reached a resolution, owing to a lack of properly contextualized finds, as well as the 'immobilization', or continued minting of popular issues (Album 1999; Fleisher \& Wynne-Jones 2010b; Horton \& Middleton $2000,94)$. The presence of coins in the archaeological assemblages of some East African coastal towns has normally been viewed as evidence of the coast's integration into the Indian Ocean world system or as a proxy for the internationalism of the Swahili towns. Coinage is seen as coincident with a commodified economy, based on quantifiable market transactions. Nevertheless, some scholars have tried to draw out social information from the numismatic evidence.

Horton and Middleton (2000, 56-9), for example, have attempted to re-interpret coastal histories through numismatic evidence. They argue that the distribution of stylistically-related coins with the names of rulers allows for a reconstruction of 'familial relationships between rulers/minters in the island towns of Pemba, Zanzibar, Mafia and Kilwa' (Horton \& Middleton 2000, 57) in the centuries between AD 1000 and 1200. Because rulers' names are in the form of ' $x$ son of $y$ ', they argue it is possible to reconstruct the movement of rulers' descendants south along the coastal corridor starting in the late tenth or early eleventh centuries AD. The coin data thus serve as an impartial data set to legitimate stories of coastal migrations, referred to as the Shirazi traditions, which have been a controversial part of coastal prehistory (Chittick 1965). The Shirazi traditions were often used as evidence of the settlement in East Africa by Persian elites who founded coastal towns. Horton and Middleton's argument uses the local production of coins, minted with town leader's names, as evidence of migrations of local leaders, rather than ones from afar.

Although the vast majority of Kilwa coins are of copper, there are smaller known assemblages of silver and gold, and other studies have attempted to understand the differences between them. The distribution of Kilwa coins of different metals suggests three possible spheres of distribution and use: copper in the Kilwa region, silver along the coastal corridor and gold used in international exchanges. Copper coins are known generally from Kilwa itself with only a few examples found outside the immediate Kilwa region, ${ }^{1}$ 
suggesting that these were a regional product used within the sphere dominated by the Kilwa dynasties. A few silver issues of Kilwa type are known primarily through finds on the southern Tanzanian coast at Kilwa and Kisimani Mafia (Chittick 1966, 11) and at Mtambwe Mkuu on Pemba Island off the northern Tanzanian coast (Horton et al. 1986). The large assemblage of silver coins (2060) from Mtambwe Mkuu is unique but the coins are 'part of the local Kilwa-type tradition' (Horton et al. 1986, 118); this find, in particular, suggests a possible coastal distribution that exceeds that of the copper coins. Gold Kilwa-type coins have been identified among chance finds acquired in Zanzibar but of uncertain biography (Brown 1991) and are unique in character, associated with a particularly wealthy and beneficent sultan, al-Hasan ibn Sulaimān, and decorated with his nickname - 'The Father of Gifts' - that does not exist on the copper coinage. It is notable that the weight of the gold coins roughly approximates the weight of a dinar, the standard Indian Ocean currency (Horton \& Middleton 2000, 93). Although it is difficult to generalize about these gold coins, of which only three are known (Brown 1991), ${ }^{2}$ it does seem that these might have served a special purpose with a more international orientation than the copper coins found in Swahili towns.

The variable distribution of Kilwa's coins thus suggests uses in local and international contexts. The minting of coins in different metals, to be used in specific spheres, is typical within Islamic coinage (Williams et al. 1997). Although the relative degree of centralization varied, dinars, dirhams and their fractions were minted in gold and silver under the control of the caliphate, located at times in Cairo, Damascus and Baghdad. Although the specific weights associated with the different mints varied slightly, and local standards were not uncommon (see Hinz 1955 for an overview), each mint maintained a standardized ratio of weights across its issue. Among the base metals many more regionallyspecific coin systems developed and the caliphate did not seek to control these. The Kilwa-type coins of East Africa were thus part of the world of Islamic coinage, referencing Allah through the honorifics associated with the Kilwa sultans, although in a profoundly local style and without mention of the caliphate. Despite their position within the corpus of Islamic coinage, the Kilwa coins were doubly divorced from centralized control. First, the East African towns were geographically distanced, on the edges of the Islamic world, not under direct political control. Minting at Kilwa would appear to have served the needs of local populations primarily. Second, the vast majority of the coins were of a metal type that was of local rather than international significance.
There is some debate over whether it is possible to understand Kilwa coins of copper, silver and gold as part of a single system or whether their use in different spheres meant that they were not just quantitatively, but also qualitatively different. Some regard the copper issues as purely local in their conception and use, and thus not easily linked systematically to gold and silver issues. For example, Lowick $(1990,160)$ argues that regional copper coinages might be considered as 'a species of bronze artefact rather than as humbler counterparts of the gold dinar and the silver dirham' (Lowick 1990, 160). Reversing this argument, Middleton (2003), uses the dichotomy drawn between money as tokens and money as quantified value (Hart 1986). He argues that gold and silver issues were markers of esteem rather than of quantified wealth, given as gifts by the sultan and kept as heirlooms rather than traded: 'The coins of gold and perhaps those of silver appear rarely, if ever, to have been used as physicallyexchanged currency but rather as counters, vouchers, or tokens of value' (Middleton 2003, 515). Copper coins are then portrayed as having small-scale abstract value, functioning as a true currency: 'The metal was widely available and the coins were used along the coast in petty exchanges between unrelated sellers and buyers' (Middleton 2003, 516).

An alternative understanding of value in coastal coinage is offered by Horton and Middleton (2000, 93), who suggest a 'trimetallic system' with a rate of 1:10:1000 between gold, silver and copper coins. The use of all coins, they argue, was 'confined to the coast itself' and used to 'facilitate business dealings between the coastal merchants themselves' (Horton \& Middleton 2000, 94). These coins would have allowed coastal merchants to 'participate within the Islamic economy and accumulate high value goods but without the need for the coins to leave the coast'. Horton and Middleton's reconstruction of a formalized system of value is intended to stand in contrast to previous ideas of East African coinage which, they argue, considered coins to be 'little more than symbolic tokens that played no part in the mercantile system' (Horton \& Middleton $2000,92)$. Their argument is based on an assessment of coin weights, and the calculated relative worth based on Portuguese historical documents. They use a basic measure called a mithqal, which is related to a weight close to $4.20 \mathrm{~g}$. This is the weight of a Cairo dinar, which Horton and Middleton $(2000,93)$ argue 'became the standard weight for Islamic coinage in the Indian Ocean'. Using the mithqal as a standard, and converting through Portuguese reis, they convert the relative values of silver and copper issues into mithqal, based primarily on references from 1505 and 1569. While the three known gold issues are each quite close in weight 
to a mithqal, the conversion rates suggest that 115 silver and 1840 copper coins would be needed to add up to the same value. Despite Horton and Middleton's arguments to the contrary, it is difficult to understand how these relative values would comprise a trimetallic rate of 1:10:1000, based either on known coin weights or historical references to value conversions. While it is clear that gold and silver issues were understood as more valuable than copper, there is even some debate over whether issues of all three metals were circulated at the same time. For example, the text used to establish the relative value of a mithqal, a Portuguese account of 1505 , explicitly states that 'there are no gold coins' at Kilwa at the time (Freeman-Grenville 1962, 108).

Each of these analyses seeks to assign a fixed value to either a part of the Kilwa coinage (gold/silver for Lowick, copper for Middleton) or to all specie (Horton and Middleton). In dividing the Kilwa coinage between coins that had abstract and token value, Lowick and Middleton indicate that certain parts of the Kilwa coinage should be understood as 'artefacts', reminiscent of the distinction drawn between gifts and commodities. We support this effort to understand the social value of coins, akin to recent understandings of other material classes in Swahili towns. For example, objects like pottery - associated with the world of Indian Ocean trade - were used for display and ritual in Swahili houses, and thus social value was of key import to the negotiation of trade relations, rather than a sole emphasis on commodified worth (DonleyReid 1990; Donley 1987; Kusimba 1999; LaViolette 2008). However, we find the contrastive nature of the distinction between 'symbolic tokens' and formalized systems of value to be overly-drawn, and question its either-or proposition. There is no reason to assume that certain parts of a coinage system were considered 'currency' while others were more 'symbolic' - this type of analysis seems to reify the division between formal and embedded forms of value, a tactic that has not served well our understandings of the Swahili.

\section{Value, commensurability and abstraction}

In his consideration of value in Swahili coinage, Middleton (2003) brings together both the 'head' and the 'tail' of the coin, as defined by Hart (1986). Token value is represented by the head, the symbolism by which money stands for something intangible, perhaps the power of a state or ruler. In contrast, the tail of the coin quantifies its value according to a universal standard, representing a more abstract definition related to accepted ratios of exchange. Rather than categorizing coinage as one or the other, the point of Hart's discussion was to highlight the dual aspect of all coinage: 'the coin has two sides for good reason - both are indispensable' (Hart 1986, 638). This has been an important step for the anthropology of money, drawing on studies that position coinage as part of the wider world of exchange, questioning its early relegation to a more abstract sphere (Malinowski 1922). Further, the recognition that coinage can have both a symbolic and an abstract value breaks down the unhelpful division between substantive and formal approaches to pre-modern economies that grew from this critique. Substantivist studies of 'primitive valuables' (Dalton 1977; Gregory 1997; Mauss 2002 [1954], 127 ) or very singular regimes of value run the risk of creating rather monodimensional versions of the ways that money might have functioned in the past. With the appreciation of both 'sides' of the coin, Hart refers rather to the collapsing of this unnecessary distinction between formal and substantive economies that has been achieved by locating coin studies within the sphere of exchange and people-object relationships.

Bloch and Parry (1989) specifically deconstruct the notion that transactions involving money are separate from other forms of exchange, situating coinage within the social and moral economy just as squarely as other forms of object. They argue that the attempt to draw a line between the two forms of value is a construct of Western understanding, not a universal given $(1989,9)$. Coins are caught up in the literature that explores gift and commodity: they are the ultimate commodity in that they embody formalized value. Yet, the dichotomy between these types of valuable has been broken down by more recent considerations of exchange relationships and the multiple ways that objects can be simultaneously alienable and inalienable (e.g. Weiner 1992). Drawing on these anthropologies, Appadurai (1986, 21-2) has suggested that objects are subject to repeated 'tournaments of value' whereby their worth is redefined for the particular moment and context. Although in his discussion those tournaments occur only occasionally, such as on market days or in a seasonal round of exchange, the notion might also be applied to daily life and the multiple negotiations of value that occur in different spheres. As such, money is part of the world of people-object relations, understood through relations of substitution rather than abstraction and commensuration (Maurer 2006; Strathern 1992). Also of key importance is the notion of historicity. Just as with other forms of embedded exchange (Munn 1986), the biographies and histories of use of coins are crucial to their ability to embody value (Hart 2000; Kus \& Raharijaona 2008; Lambek 2001). Coins can therefore be seen as meaningful objects that function in society, allowing for exploration of the ways in which value 
in coinage is caught up with issues of power, ritual and daily experience.

The relationship of value to authority and to the determination of value by the powerful is one aspect that recurs in the anthropological literature. Money is one of the key ways that people will experience the power of the ruler or state in their everyday lives (Palmer 1998). This has been pursued particularly in the anthropology of Africa, as coinage was often introduced by colonial powers, and thus the ability of those authorities to assign value comes sharply into relief (Guyer 2004). Comaroff and Comaroff (2006, 116-17) for example, link the process of abstraction of value to a 'rationalization' attempted by evangelical Europeans among the southern Tswana; in practice, this form of value existed in tandem with more local forms of exchange. Even where the transition to an abstract form of wealth was accomplished, beads took on the role of a currency for some time. ${ }^{3}$ Thus, even in a context in which missionaries were successfully producing a commodified sense of the world, in which objects previously beyond purchase were becoming available, the form of the currency chosen remained up for grabs, with coins and cattle forming competing regimes of value.

The entanglement of evangelism and power in this example is of interest, as spiritual authority is also crucial to the 'head' of the coin. Godelier (1999) stresses the importance of intangible forms of authority and suggests that the ability of any sovereign or worldly power to define value rests on a belief in a transcendental authority: 'money must harbour the presence of the gods, be stamped with their symbols or with the seal of the state or the effigy of the king' (Godelier 1999, 166). He gives the example of the US dollar and its reference to the power of God as guarantor of the power of the state. In practice, such supernatural concerns in anthropologies of money are mainly approached through the practical ways that coins have functioned as part of spiritual life. In Lambek's (2001) study of money in the Sakalava polity of northwest Madagascar, this aspect of coins is woven together with their religious significance, and particularly their links to history. His analysis complicates the relationship to power, with money providing value to the state rather than vice versa. The material character of the coinage is important, and particularly its material of manufacture and the image on the face: standing figures are particularly valued. Yet the key element of Lambek's analysis is the way in which the uses of coins determine their value, as well as providing ongoing authorization of the royal clan. Thus, the materiality is subordinate, as even base modern coins, used appropriately, can take on the functions of more precious metals:
Everyday currency cannot replace the coins in their essential uses though it does implicitly stand in for them in the monetary prestations that are a central part of peoples' interactions with living royals and royal ancestors. (Lambek 2001, 738)

In the Sakalava context, money materializes social relations rather than dissolving them via its abstract qualities; it is central to the rituals and practices that provide the ongoing legitimation of royal authority. Lambek (2001, 739-40) suggests that this happens in three ways: through association with overseas connections; through production of generational continuity in the tromba religious cults, collapsing historical claims to legitimacy into the present; and as a means through which commoners approach the royalty in ritual contexts. These ritual contexts are important to the ongoing significance of money, and its association with history and commemoration. As well as demonstrating another means through which coin value is negotiated, this suggests a recursive relationship between economy and ritual across which coins might move. As such, they become both substitutable (as abstract worth) and unsubstitutable (as citations of the history of circulation), straddling the divide between commodity and object and complicating our understandings of their social role.

In another Madagascan example, Kus and Raharijoana (2008; forthcoming) have explored the ways that people 'find value' in money, defining the worth of coinage from the bottom up. Coinage, often imported, appears in their examples in numerous contexts. In many of these, coins did not serve as money, but were removed from circulation and pressed into service as jewellery, raw material for other metal objects, or ritual offerings. This was, they suggest, at the heart of the problem of 'disappearing coinage' recognized by Portuguese colonial authorities in their historical interactions with the island (Kus \& Raharijaona forthcoming) and continues to be the case today. Thus, instead of circulation and use necessarily providing value and authority to the ruling authorities, it can serve to subvert that authority through the 'economics of the street', as people find value in their own ways. In the Madagascan context this seems to have included aesthetic and sonorous value (the jingling of coins as jewellery) as well as the quantifiable value of the coins and the specie they contained.

These anthropological insights into value, power and circulation of coinage suggest that archaeologists might find rich insight into local material and social worlds through a nuanced analysis of money. Extending some of these understandings into the past has - of course - its own set of difficulties. Kus and Raharijaona (forthcoming) show one way in 
which their insights might be historicized, pointing to the use of coins as jewellery in burials from the eleventh century onwards on Madagascar (Verin $1986,4)$. It is clear that symbolic archaeologies that seek to understand object relationships and interactions cannot ignore the importance of coins to those understandings. This realization is also reflected in the growing emphasis within archaeological numismatics on 'site finds' - contextualized coins that can speak to aspects of value and usage - which has brought that subdiscipline increasingly into line with more anthropological archaeologies. Recent coin studies stress the pursuit of monetary history, as opposed to 'numismatics', the latter seen as a more descriptive approach (Spufford 1988; Williams et al. 1997). Through a consideration of context, distribution and relationship to other artefacts and materials, we can move towards understanding how coins functioned as part of particular social worlds.

Spiritual and ritual concerns are - for example highlighted by Theuws's (2004) study of gold coins in seventh-century Europe, in which he uses the symbolism of the coins to argue for a link between value and the cult of saints found throughout the Merovingian world. Coins were struck and used on market days, which were themselves under the protection of a saint. Thus the value of the coins was linked to the power of the saint, and not simply to the specie value or any secular power (Maurer 2005 makes a similar argument for the monetary reforms of 'Abd al-Malik, an Umayyad caliph of the seventh century AD).

Coin finds in African-American burials suggest that the ritual practices involving coins can be based on both their symbolic and formal properties. At the New York African Burial Ground, coins 'were placed on the eyelids, in the hand(s) or pocket, scattered inside the coffin, or left on the grave surface' (Perry \& Woodruff 2006, 425). Researchers have interpreted the placement of coins on the eyes and in the coffin as currency to be used by the departed to return back to homelands (Watters 1994, 64). Although this represents a ritual act, the fact that the coins found in graves were the 'most common denominations circulating among captive Africans' suggests that they were also recognized for their formal value. Placement of coins on the eyes had a functional purpose, keeping the eyes firmly closed, but also indicated a fear that the deceased might look to the living to take them into death (Coffin 1976, 97). In addition to coins placed within the coffin, coins on African-American graves themselves are believed to be one artefact among many (bottles, foil, shells) that represent the 'flash of the departed spirit' through their reflective and shiny appearance (Thompson 1983, 142). Thus, coins in African-American contexts provide an important example of how meaning can be both formal and substantive simultaneously, as Perry and Woodruff $(2006,425)$ note, 'coins at the African Burial Ground [in New York] may have served dual multivalent purposes: both the pragmatic (closing of the deceased's eyes) and the spiritual'.

A more contextual analysis is provided by monetary histories of Iron Age Europe. Kilger (2008) echoes some of the Madagascan ethnographies in his exploration of aesthetic qualities and object equivalencies for silver coinage in the Early Viking Period, which is seen as functionally equivalent to certain object categories such as rings and ingots. The values of both were determined by their wholeness, as opposed to fragmented or 'hack' silver; the specie value might be the same, but is subordinated to the formal properties of the objects.

These numismatic studies alert us to the possibilities for exploring value through context, just as the anthropologies of money and exchange suggest that coins might have had a social role in many spheres. The peculiarities of the Swahili world suggest that such a study could be of particular interest here. The Swahili, and the town of Kilwa Kisiwani in particular, straddled several systems of value, and were a society in which both objects and claims to historicity were of crucial social importance. The contextual data from Songo Mnara should enable us to approach these issues of value and use, and go beyond a simple link with external trade, or the division between internal or external logics of value for these interesting artefacts.

\section{Systems of value in East African coinage}

The finds from Songo Mnara allow us to evaluate sources of value in three ways. First, the coins provide data with which to evaluate the links between metal specie (represented by weight) and value; this is achieved with particular reference to the postulated 'trimetallic' system of value proposed by Horton and Middleton (2000, 93-4). Second, the ability to explore a contemporaneous collection of coins, with distinctive ratios of particular sultans represented, permits an exploration of value as related to the reign and commemoration of particular rulers (Fleisher \& Wynne-Jones 2010b). Finally, contextual information from excavations at the site allows us to think through the ways that coins were used in the daily life of Songo Mnara, offering a glimpse into the ways that value was materialized in use. These aspects provide a means for thinking about Kilwa-type coins as both a currency and as 'bronze artefacts', allowing us to consider the symbolism and social function of coins, as well as their use in transactions. 
Table 1. Sultans represented on coins from Songo Mnara.

\begin{tabular}{|l|l|c|}
\hline Sultan & Date & No. \\
\hline 'Ali ibn al-Hasan & eleventh century & 6 \\
\hline Dā'ūd ibn Sulaimān & early fourteenth century & 1 \\
\hline Sulaimān ibn al-Hasan & early fourteenth century & 2 \\
\hline al-Hasan ibn Sulaimān & fourteenth century & 11 \\
\hline Sulaimān ibn al-Husain & fourteenth century & 2 \\
\hline Nasir al-dunya & fifteenth century & 11 \\
\hline unknown & & 31 \\
\hline Total & & $\mathbf{6 4}$ \\
\hline
\end{tabular}

\section{Excavations and the coin assemblage}

The Songo Mnara coin assemblage includes 64 coins of copper or bronze (Table 1). As discussed, these were recovered through broad-exposure excavations using a single-context recording system. The aim of fieldwork at Songo Mnara is to recover aspects of the uses of space and the patterning of artefacts in the urban landscape (Fleisher \& Wynne-Jones 2010a; WynneJones \& Fleisher 2010) and thus close attention was paid to context. Fifteen units were excavated during a season of research in 2009, including a complete house structure, test pits inside a second house, trenches across activity areas such as the well and the bases of staircases, and the excavation of an area around a coral-built tomb. As well as excavating by context, the sediments were sampled for macrobotanical flotation, geochemical analysis, phytolith extraction and were sampled for microstratigraphy. All sediments were sieved through a $2 \mathrm{~mm}$ mesh. This combination allowed for extremely tight control over both stratigraphy and artefact associations, and a clear sense of the contexts from which coins were recovered.

Space does not permit a full description of the archaeology of the site, but several aspects are salient to the current discussion. First, it is clear that Songo Mnara was occupied for only a relatively short period of time between the fourteenth and early sixteenth centuries. The artefacts, dated through associated imports, all come from this tightly delineated period, and are clearly stratified, with the earliest fourteenth-century deposits distinguishable from the later through the development of the structures and associated middens. Second, it is possible to link all finds to particular domestic or ritual activities occurring during the period of this occupation as defined through other means. This level of detail is rare on the Swahili coast and allows an exploration of object associations that has not previously been possible.

Among the 64 coins, 33 were identifiable while 31 were unidentifiable but their size and material suggest they are Kilwa-type coins as well. The coins were identified by Helen Brown, formerly of the Heberden Coin Room, Ashmolean Museum, Oxford.
Table 2. Location of coins found at Songo Mnara.

\begin{tabular}{|l|l|c|c|c|}
\hline Trench & Location & No. & $\begin{array}{c}\text { No. } \\
\text { identifiable }\end{array}$ & $\begin{array}{c}\text { No. of } \\
\text { fragments }\end{array}$ \\
\hline SM002 & house exterior & 2 & 2 & 0 \\
\hline SM004 & room in House 44 & 1 & 1 & 0 \\
\hline SM005 & iron-smithing area & 3 & 3 & 0 \\
\hline SM006 & outside well & 1 & 0 & 0 \\
\hline SM007 & open area & 3 & 0 & 3 \\
\hline SM010 & $\begin{array}{l}\text { back room in } \\
\text { House 44 }\end{array}$ & 36 & 18 & 6 \\
\hline SM011 & Earthen house? & 8 & 3 & 0 \\
\hline SM012 & around tomb & 7 & 5 & 2 \\
\hline SM013 & house exterior & 2 & 1 & 0 \\
\hline SM015 & room in House 23 & 1 & 0 & 0 \\
\hline Totals & & $\mathbf{6 4}$ & $\mathbf{3 3}$ & $\mathbf{1 1}$ \\
\hline
\end{tabular}

The identifiable coins were associated with six different sultans (Mitchell 1970; Walker 1936; Table 1). Most of the coins date from the early fourteenth to late fifteenth century $(n=27)$, but six coins, of the 'Ali ibn al-Hasan type, are of a type assigned to the eleventh century. Three issues dominate the assemblage, those of 'Ali ibn al-Hasan, dated to the eleventh century, al-Hasan ibn Sulaimān of the fourteenth century, and a fifteenth-century type known as 'Nasir al-Dunya' unrelated to any specific sultan (Mitchell 1970). The coins were spread across the spaces of the site (Table 2; Fig. 3), seemingly representing their circulation among the population. The location of most of the coins suggests that they were lost in the course of everyday actions. For example, the 36 coins in SM010 (a room in House 44) were incorporated into several layers of a midden deposit, linked to cooking through stoves and faunal remains, as well as plentiful evidence for burning. Spindle whorls also testify to work on the production of cotton in this house, and probably within this room. The coins are therefore part of the domestic environment, probably lost during one of the activities identified here. Likewise, the coin in SM006 sits within a compacted context of ceramics by the side of the well, evocative of the activities of the inhabitants as they went about their daily round of activities. These associations confirm the common use and likely small value of the coins, as well as their circulation among the general populace.

\section{Defining value: specie and standardization}

In considering the links between value and metal specie at Songo Mnara, we assess the degree of standardization of weight, which would be expected if the coins held a set value related to bullion. Although we deal only with the copper coins, it is useful to consider how the Songo Mnara assemblage might fit into Horton and Middleton's (2000, 93-4) trimetallic system of gold, 

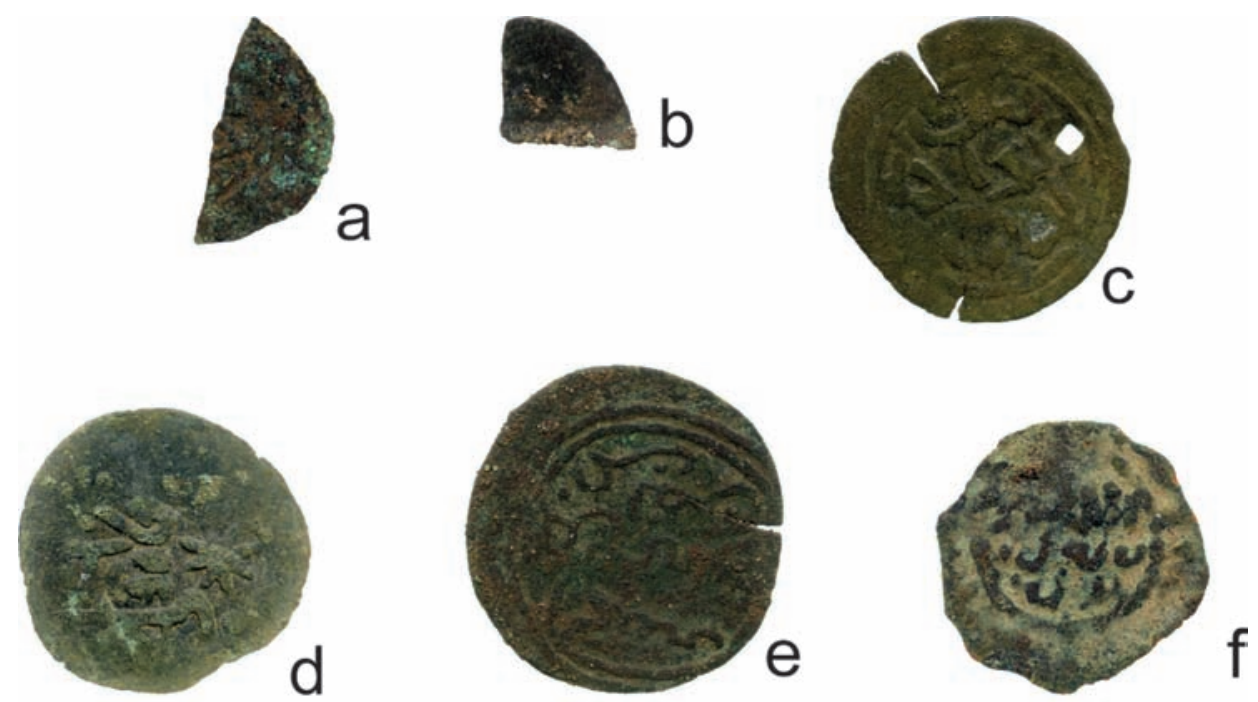

Figure 4. Coins from Songo Mnara (numbers = excavation find number): a) half coin, unknown (10223); b) quarter coin, unknown (10245); c) pierced, al-Hasan ibn Sulaimān (10122); d) 'Ali ibn al-Hasan (10053); e) al-Hasan ibn Sulaimān (10213); f) Nasir al-Dunya (10234).

silver and copper coins. The coin weights from the Songo Mnara assemblage contradict Horton and Middleton's $(2000,93)$ claim that copper coins were 'a fairly consistent $2.6 \mathrm{~g}^{\prime}$; the average weight of all identifiable coins was $1.6 \mathrm{~g}$, with individual types showing only small differences in their average weight. This fact alone seems to cast doubt on the idea that copper coins were linked into a value system that encompassed silver and gold through specie weight. Indeed, the weight of copper coinage is far from uniform (Table 1) and it is not easily possible to distinguish a 'Kilwa standard'. Brown has suggested that at Shanga on the northern Kenya coast (Horton 1996, 371) the greater degree of standardization of size, as opposed to weight, suggests that this aspect was more consistently attended to, probably through pouring the metal into a standard size of mould. The Songo Mnara data support this notion, with highly variable weights and sizes much closer to a standard diameter.

One way to measure variability within the assemblage is to use the coefficient of variation $(\mathrm{CV})$, which is the result of dividing the standard deviation by the mean (Table 3). This allows for the measurement of variation independent of the actual size of the mean or standard deviation in a sample (Eerkins \& Bettinger 2001, 498). CV values can be understood within a scale in which 0.58 represents a fully random population, while values close to 0.01 represent standardized populations. As Table 3 shows, coin diameters have a low $\mathrm{CV}$ value, indicating less variability within the sample, while weights are much more variable. Thus there is little evidence to support the idea that copper coins were valued based on specie weight.

Even though copper coin value does not seem to have been derived from the quantity value of the metal they contained, they are still likely to have been considered objects of currency, perhaps in established conversions of number of coins (rather than conversions based ultimately on weight). The discovery of several coin fractions at Songo Mnara, primarily half and quarter fragments (Fig. 4) suggests that the value of a coin could be divided, reflecting a recognized rate of exchange within the town. Interestingly, all of the coins recovered from a possible wattle-and-daub house (SM007) were clipped or fragments; as this structure is presumed to have been linked to a nonelite portion of Songo Mnara's community, it might be assumed that they were performing smaller-value transactions. Clipped coins were also found in several other contexts, including a stone-built house (SM010) and around a tomb (SM012).

The quotidian circulation of the coins, attested by the broad spread of their find spots and the artefact associations discussed above, suggest a rather mundane position for these artefacts within the material repertoire of the town, located in the sphere of the household economy. As well as the cooking area finds (SM010) and a coin lost by the well (SM006) these include lost coins beneath the doorway of a domestic structure (SM002, SM013) and on the packed-earth floor of a likely earthen house (SM011). The association with the domestic sphere suggests that women may have carried and used these coins: the activities 
Table 3. Coin weights and diameters: averages, standard deviations, and coefficient of variation.

\begin{tabular}{|l|c|c|c|}
\hline \multirow{2}{*}{ Coin type } & STDEV & AVERAGE & \multirow{2}{*}{ CV } \\
\cline { 2 - 3 } & wt $\mathbf{( g )}$ & wt $\mathbf{~ g})$ & \\
\hline All fourteenth- to fifteenth-century coins $(n=27)$ & 0.51 & 1.67 & 0.303 \\
\hline Nasir al dunya $(n=11)$ & 0.22 & 1.29 & 0.173 \\
\hline al-Hasan ibn Sulaimān $(n=11)$ & 0.43 & 1.91 & 0.226 \\
\hline 'Ali ibn al-Hasan $(n=6)$ & 0.19 & 1.08 & 0.180 \\
\hline \multirow{3}{*}{ Coin type } & STDEV & AVERAGE & \multirow{2}{*}{ CV } \\
\cline { 2 - 3 } All fourteenth- to fifteenth-century coins $(n=27)$ & 1.30 & 21.45 & 0.061 \\
\hline Nasir al dunya $(n=11)$ & 0.84 & 20.70 & 0.041 \\
\hline al-Hasan ibn Sulaimān $(n=11)$ & 1.28 & 21.98 & 0.058 \\
\hline 'Ali ibn al-Hasan $(n=6)$ & 1.40 & 20.06 & 0.070 \\
\hline
\end{tabular}

associated with these finds are traditionally seen as the preserve of women, a particular linkage of the back rooms of houses is established in ethnographies (Donley-Reid 1990). If so, then the pattern in which men are more likely to control cash transactions on the Swahili coast (Caplan 1982, 40) might be seen to be a much more recent phenomenon.

\section{Determining value: power and control}

In the absence of a quantifiable bullion value, it seems that the copper coins may have derived more of their value from symbolic aspects, as was suggested by Middleton (2003) for the gold and silver issues, recalling Hart's (1986) 'head' of the coin. This source of value need not have meant that they were removed from the world of everyday transactions, as Middleton concludes, but could have been part of those transactions, and an important source of legitimation for the currency. There are at least three ways through which we might read the symbolic aspects of Kilwa coins: as representations of knowledge, literacy and craftsmanship; as links to broader sub-Saharan African meanings associated with copper; and as sites of commemoration.

As tokens of the sultan's authority coins might have referenced the skills of craftsmanship and literacy involved in their manufacture and subject to centralized control. Kilwa was but one of many coastal polities along the East African coast during the medieval period, but the only one that consistently and enthusiastically minted coins. Rather than understanding the production of coins as purely a functional requirement for international or local commerce, we also need to recognize them as a demonstration of the ability of the sultan of Kilwa to control particular types of knowledge (Killick 2009). These knowledge systems include the production of dyes, the preparation of copper and the minting of issues. Additionally, the public control over, and presentation of, Arabic phrases on the coins represent a rich knowledge of the Islamic world of coinage, as well as privileged forms of literacy; in Swahili towns Arabic was likely related only to the practice of religion, with Swahili as the language of daily life.

The debates about the specie value of Kilwa coins have always assumed that the use of copper was simply due to its small relative value as compared with silver or gold. This, however, is viewing Kilwa coins through the lens of Indian Ocean regimes of value in which the insignificant value of copper was relegated to local currencies. In contrast, in precolonial sub-Saharan Africa, copper was often used as both a medium of exchange and a symbol of power and authority (Herbert 1984). The control of copper at the coast then, and its conversion into a medium of petty exchange for coastal towns, was thus a powerful statement about coastal leaders in relation to centres of power on the continent. That the leaders at Kilwa were concerned with the negotiation of African and Indian Ocean systems of value is written into the origin story of Kilwa itself, in which a newly-arrived sultan brokers with local leaders in cloth, another important and meaningful commodity (FreemanGrenville 1962; Prestholdt 1998). Although finds of Kilwa coins outside of the region are rare, it is thus perhaps no coincidence that the Kilwa coins found in the larger Indian Ocean were of gold, while those found at Great Zimbabwe were of copper.

The evidence of the ratios of different sultans also suggests that some of their value was linked to the prestige of those rulers and particularly to their roles in the history of Kilwa. The preponderance of Kilwa coins relating to particular sultans has long been noted among the various hoards and collections subjected to analysis; previously, it had been presumed to relate to chronology, with the most numerous coins thought to reflect the contemporary ruler at the time of deposition. Invariably, the most numerous issues have been those of two sultans (Table 4), 'Ali ibn alHasan (eleventh century) and al-Hasan ibn Sulaimān 
Table 4. Percentages of different sultans from Songo Mnara and from other known collections.

\begin{tabular}{|c|c|c|c|c|c|c|c|}
\hline & $\begin{array}{l}\text { Songo } \\
\text { Mnara }\end{array}$ & $\begin{array}{c}\text { Songo } \\
\text { Mnara } \\
\text { (without } \\
\text { unknowns) } \\
\end{array}$ & $\begin{array}{c}\text { Hoard A } \\
\text { (Walker } \\
\text { 1936) }\end{array}$ & $\begin{array}{c}\text { Hoard C } \\
\text { (Walker } \\
\text { 1936, 80-81) }\end{array}$ & $\begin{array}{c}\text { Hoard } 1 \\
\text { (Walker } \\
\text { 1939) }\end{array}$ & $\begin{array}{c}\text { Hoard } 2 \\
\text { (Walker } \\
\text { 1939) }\end{array}$ & $\begin{array}{c}\text { Hoard } 3 \\
\text { (Walker } \\
\text { 1939) }\end{array}$ \\
\hline 'Ali ibn al-Hasan & $9.4 \%$ & $18.2 \%$ & $25.7 \%$ & $20.6 \%$ & $32.3 \%$ & $33.3 \%$ & \\
\hline Dā'ūd ibn al-Hasan & & & $2.6 \%$ & $0.6 \%$ & $2.4 \%$ & $1.8 \%$ & \\
\hline Hasan ibn Ṭālūt & & & $0.1 \%$ & & & $0.9 \%$ & \\
\hline Sulaimān ibn al-Hasan & $3.1 \%$ & $6.1 \%$ & $0.2 \%$ & $9.4 \%$ & $17.3 \%$ & $17.5 \%$ & $17.4 \%$ \\
\hline Dā'ūd ibn Sulaimān & $1.6 \%$ & $3.0 \%$ & $5.6 \%$ & $2.8 \%$ & $6.3 \%$ & $0.9 \%$ & \\
\hline Sulaimān ibn al-Husain & $3.1 \%$ & $6.1 \%$ & $14.2 \%$ & & $0.8 \%$ & & \\
\hline Muhammad ibn Sulaimān & & & & & $0.8 \%$ & $0.9 \%$ & \\
\hline al-Hasan ibn Sulaimān & $17.2 \%$ & $33.3 \%$ & $49.0 \%$ & $22.8 \%$ & $32.3 \%$ & $43.0 \%$ & $2.2 \%$ \\
\hline Unknown & $48.4 \%$ & & $2.5 \%$ & $8.3 \%$ & $7.9 \%$ & $1.8 \%$ & $80.4 \%$ \\
\hline Nasir al-Dunya & $17.2 \%$ & $33.3 \%$ & & $35.6 \%$ & & & \\
\hline
\end{tabular}

(early fourteenth century), and thus their reigns have been seen as periods of particularly energetic minting. While this may have been true, particularly for al-Hasan ibn Sulaimān, who is also responsible for the gold coins discussed above, the Songo Mnara evidence suggests that relative proportions are not a good guide to chronology (Album 1999; Chittick 1965; Fleisher \& Wynne-Jones 2010b). The temporally-restricted occupation of Songo Mnara, covering at most 200 years between the late fourteenth and sixteenth centuries, has yielded proportions of the different issues comparable with the other collections known. Given that the coins do not seem to have been curated, but instead subjected to daily use, these proportions indicate that coins were 'immobilized': minted and used long after the deaths of the individual sultans. This would suggest that those sultans whose issues were reproduced (the sultans associated with the founding of the Shirazi and Mahdali dynasties) were particularly valuable as symbols, guarantees of authority. The ancestry of the sultanate, from which they may have derived some of their continuing authority, would be reaffirmed constantly by the circulation of coins belonging to their illustrious ancestors. The ancestry of the town of Kilwa itself would also be continuously promoted through the recognition of the ongoing ability of the early sultans to guarantee contemporary transactions. While these symbolic effects of the coins were important to the reckoning of coin value, coins were also likely related to the practice of power within the Kilwa region.

\section{Symbols and practice}

As well as providing a source of value for the coins themselves, the continuing circulation of the coins would have been part of the way that the townspeople of Songo Mnara experienced the rulers in their every- day lives. As such, they would have provided part of the ongoing authorization of power for the sultans, through the ideology of symbols controlled by them (Miller \& Tilley 1984). There are obvious parallels here with Lambek's (2001) insights, discussed above, into coinage and Madagascar's Sakalava royalty. For Lambek, the historical aspect of the coins he studied gave them an enduring power, as a symbol of the wealth and generational continuity of the royal dynasties, as well as through their material association with those groups. Importantly, the coins derived much of their power in this regard from their incorporation into ritualized actions. Likewise, as the coins moved through the ritual sphere, they provided commoners with a source of power, a means of approaching the royal dynasties and experiencing them in their everyday lives.

Commemoration and the historical reproduction involved in the circulation and ritual use of the coins extends the 'two sides' recognized by Hart (1986), both of which are concerned with coins as currency, and speak instead to different aspects of the coins' social value in use. Such a symbolic role for coinage has been little recognized archaeologically, particularly as it might exist simultaneously with its function as currency. Yet there are aspects of the Songo Mnara coins that might suggest similar symbolic associations, including the use of coins as commemorative objects, both in daily use and as ritual deposits.

The repetition of particularly powerful sultans as common issues among the coins already suggests that they may have served a commemorative purpose. It may be coincidence that these sultans are the reputed founders of the sultanate at Kilwa ('Ali ibn al-Hasan) and the most famed and generous sultan of the Mahdali dynasty (al-Hasan ibn Sulaimān), but it may also speak to the power of their memory in the ongoing 


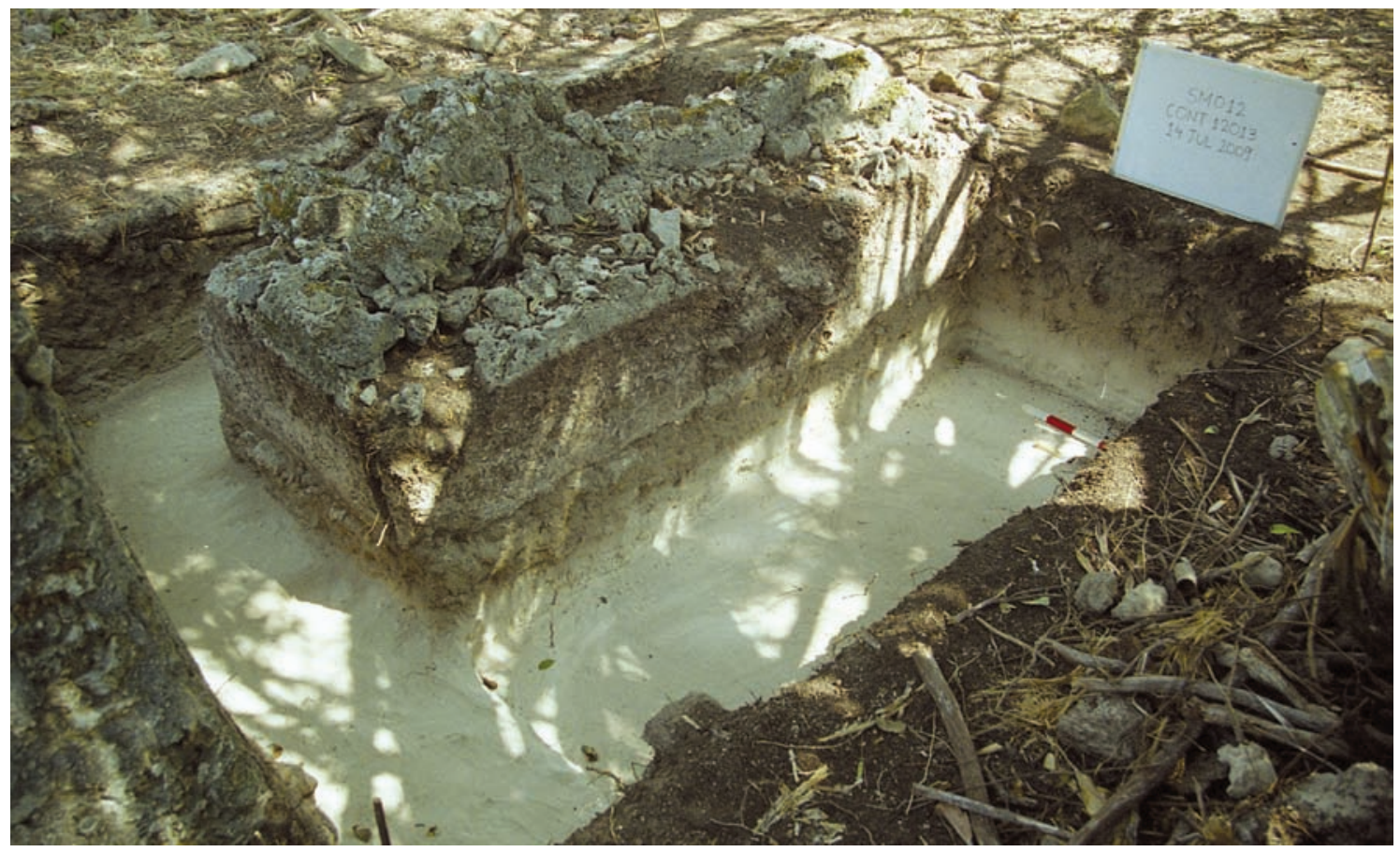

Figure 5. Trench SM012, area excavated surrounding a coral rag, stepped tomb.

importance of the sultanate. As in Lambek's study, this feature also provides an important bridge between the gold and silver currency and the copper coins used for 'petty exchange', as these might be metonymic in their ability to reference a wider world of coinage and the power of the associated sultanate.

The contexts in which coins were found at Songo Mnara also suggest their incorporation into commemorative activities. Seven coins were recovered from an excavation unit (SM012) around a fifteenth-century tomb (Fig. 5). These excavations were designed to explore the possibilities for an archaeology of offerings at the tomb, and exposed various linked features at a single level, presumed to be the ground level at the time of Songo Mnara's occupation with no evidence for disturbance. In addition to the coins, this included phytolith evidence for palm fronds laid at the two ends of the tomb, several ceramic vessels including a lamp, and a series of rounded pebbles which are known historically as offerings. Contemporary practice also suggests that coins would have been left near important tombs, by family members referencing and celebrating their ancestors, and by others seeking favour from important deceased individuals. At Songo Mnara today, offerings are left on the tomb of a local holy man or sharif in the hope of blessing or perhaps intercession in the daily life of the donor. The coins recovered in SM012 were of two types, one known as Nasir al-Dunya, and the other with the inscription of al-Hasan ibn Sulaimān. As with the Madagascan example, the use of coins relating to this latter sultan, renowned for his generosity, could have been more than coincidental. By using these coins, the process of commemoration is twofold, remembering the individual buried within the tomb, and circulating the ongoing memory of a beneficent sultan.

The removal of coinage from circulation noted by Kus and Raharijaona (2008; forthcoming) speaks to another way that coins might find value through use. Coins were valued for their aesthetic or sonorous properties. In archaeological contexts, this might be indicated by the piercing of coins for adornment rather than trade. At Songo Mnara, a single pierced issue of al-Hasan ibn Sulaimān (Fig. 4) was found in SM010, a midden deposit associated with domestic waste and also one of the richest sources of coins at the site. Yet the hole punched into the rim of the coin is suggestive of its being worn as a pendant. Freeman-Grenville $(1957,156-7)$ suggested a similar use for the high number of pierced specimens (34 out of 675) among one of the collections of Kilwa-type coins that he studied. He thought that the piercings related to the coins being strung for adornment, either around the necks or in the ears of local women; it was even suggested that those with two holes were strung on nose rings. Owing to the lack of context for Freeman-Grenville's coins, it was impossible to know if the piercing was contemporary with the 
period during which the coins were in use; the Songo Mnara coins demonstrate that this is probable, and that both monetary and decorative uses for the coins existed simultaneously.

In fact, although never discussed, pierced coins seem to have been common in the various Kilwa collections. The typologies rarely mention this feature, except for a single mention in Walker and FreemanGrenville $(1956,54)$, no doubt included because the coin was illustrated. The museum catalogues of those places where Kilwa coins have come to rest give a more complete picture. The Sylloge of Islamic coins in the Ashmolean (Album 1999) shows four pierced specimens out of the 82 Kilwa coins shown. Even more are in evidence in the Fitzwilliam Museum's online catalogue (http://www.fitzmuseum.cam.ac.uk/dept/ coins/opac/), which contains 28 pierced Kilwa coins out of 179 listed; piercing is particularly common with their issues of 'Ali ibn al-Hasan (6 out of 47), al-Hasan ibn Sulaimān (14 out of 47) and Dā'ūd ibn Sulaimān (4 out of 5). Interestingly, one of the pierced coins in the collection is also described by Walker $(1939,223-4)$ who does not mention the piercing. This suggests that others of those coins described by him might also have been pierced and that it would not have shown up in his descriptions.

The pierced coin in SM010 shows the contemporaneity of coins as currency and coins used for decorative purposes. Their possible use for adornment places them within the world of embodied identities at Songo Mnara. As with the examples placed on the tomb, these coins would have been taken out of circulation, although in this case perhaps temporarily, their value instead being put into practice as part of individual display which simultaneously referenced the other uses of the coins. We can only speculate about the symbolism of these coins as personal items of adornment, though they have a place within a social world that emphasized cosmopolitanism and material display. A tantalizing passage in one discussion of the format of Kilwa coins also suggests that they might themselves have been shaped by their associations with this use. Brown $(1993,14)$ states that the unique format of Kilwa's coins, on which the ruler's name is paired with a rhyming Holy Name of Allah, has parallels 'outside the realm of coins, on amulets and talismans'. For Brown, this demonstrates the gulf separating Kilwa's coinage from the international Islamic monetary system and reinforces her suggestion that 'these low-value coins, whether copper or tiny silver, may perhaps best be thought of almost as token currency' $(1993,14)$. Here, though, we consider that the rich world of use that is hinted at by Kilwa coins in context might have been part of what gave that currency local relevance and value. Rather than seeing parallels with amulets or talismans as detracting from their value, the use of coins as items of decoration, coupled with their possible ritual significance and reference to amulet inscriptions, might have been a part of the ways that coins functioned and were valued within Swahili society.

\section{Conclusion}

Consideration of Songo Mnara's coins and their contextual associations does not, then, allow neat categorization into a broader system of abstracted value. Indeed, the chronological control available at Songo Mnara suggests that even a neat correlation with Kilwa's dynastic succession is not possible, and factors like immobilization will have complicated the assemblages that remain. The excavated examples instead allow us to consider the coin data as the residue of contemporaneous activities, rather than regarding the composition of the assemblage as an accident of preservation, or product of a lack of stratigraphic control. As such, we are able to explore the world of use and meaning for Songo Mnara's copper coinage; this leads us on to an analysis of their place in a larger system.

It seems that the coins of Songo Mnara circulated within the town, probably as a currency for local transactions, as indicated by the clipped coins found, as well as by the widespread nature of the finds and their links to mundane daily contexts. This local usage at Songo Mnara seems to mirror a similar pattern at Kilwa Kisiwani itself, as well as perhaps the Mafia archipelago, where most Kilwa coins have been found. This pattern of distribution varies from that for the silver issues, which are known primarily from the hoard on Pemba, and the gold coins, of rare and unknown distribution. Silver coins, for example, might have been a medium for exchange between different coastal polities. The limited number of gold coins and their unique inscriptions suggest that the gold coins of Kilwa might have served a specific function as gifts or tribute, rather than currency for trade. This sultan is also known to have made a pilgrimage to Mecca, which might have been an opportunity for distribution. This echoes Middleton's (2003) suggestion for their use as tokens of the sultan's authority, although there is no archaeological evidence for his assertion that many would have been stored in the houses of wealthy or successful merchants.

Despite their function as currency within the town, it is suggested here that the source of value for the coinage did not derive from a simple equation with quantified bullion, and that they might have had 
simultaneous symbolic and decorative uses. The lack of standardization of weight observed among the copper coins contrasts with a very consistent decorative style. The continued popularity of particular issues, especially those of famous and powerful sultans, suggests a derivation of value that was linked to that power. This was one form of commemoration suggested for the coins, as they would have been linked with the ongoing memory of certain rulers.

The data on symbolic aspects of the coins are more speculative, but the association with tomb contexts and offerings suggests another form of commemoration: an active memory practice that could have linked individual ancestors with more powerful group ancestors through commemorative ritual. In the wake of the Madagascan examples, we suggest that this could also have fed back into the value accorded to the coinage. Further, we speculate that aspects of use and the aesthetic properties of the coinage might have been part of how people found value in their currency, perhaps outside the realm of exchange. Objects of symbolic importance within Swahili towns were often displayed in public and private spaces, and the piercing of some coins, probably for display on the body, reinforces this attribution of symbolic importance.

The consideration of value and use among Songo Mnara's coins therefore uncovers a rich world of symbolism that goes beyond the simple use of copper coins for 'petty exchange'. By considering these coins, we hope that we have demonstrated the potential for coins to feed back into other archaeological considerations of material symbols, and made an argument for their implication in the social world, rather than simply as items of abstract value for commodity exchange. At Songo Mnara, the two 'sides of the coin', represented by token value and exchange value, seem to have been intertwined in a complex world of use, in which coins might move in and out of circulation as currency or as ritual or decorative objects. A symbolic archaeology that seeks to understand the ways that things functioned in society, simultaneously defining both objects and people, must engage with these 'bronze artefacts' and their attendant levels of value.

\section{Acknowledgements}

Research at Songo Mnara was funded primarily by Rice University, through the Social Sciences Research Institute and the Archaeological Field School of the Department of Anthropology. The British Institute in Eastern Africa and The Leverhulme Trust provided supplementary funding. The identification of the Kilwa coins from Songo Mnara was made by Helen Brown, formerly of the Ashmolean Museum (Oxford), to whom we are particularly indebted.
We were also assisted by the staff of the Fitzwilliam Coins and Medals Department, particularly Jonathan Jarrett. We have benefited from discussions with Robert Blunt and John Perkins on aspects of coinage and value. We are grateful to Søren Sindbaek for his comments on the initial draft, and to three external reviewers for helpful suggestions.

\section{Notes}

1. One single example was found at Great Zimbabwe (Huffman 1972).

2. Brown does report four gold coins in other publications (1993; Horton 1996) but it seems likely this is an error, since the publication of the actual coins refers only to three.

3. The use of beads, or cowries, as currency has been documented in numerous other instances, particularly along trade routes that had allowed precolonial contact with European trading regimes (Pallaver 2009; contributions to Stiansen \& Guyer 1999). As in the Tswana example, these were engaged with according to existing structures of meaning (Ogundiran 2002).

$$
\begin{array}{r}
\text { Stephanie Wynne-Jones } \\
\text { Department of Archaeology } \\
\text { University of York } \\
\text { King's Manor } \\
\text { York } \\
\text { YO1 7EP } \\
\text { UK } \\
\text { Email: stephanie.wynne-jones@york.ac.uk } \\
\text { Jeffrey Fleisher } \\
\text { Department of Anthropology } \\
\text { MS 20, Rice University } \\
\text { P.O. Box 1892 } \\
\text { Houston, TX 77251-1892 } \\
\text { USA } \\
\text { Email: jfleisher@rice.edu }
\end{array}
$$

\section{References}

Album, S., 1999. Sylloge of Islamic Coins in the Ashmolean: Arabia and East Africa. Oxford: Ashmolean Museum Press.

Appadurai, A., 1986. Introduction: commodities and the politics of value, in The Social Life of Things: Commodities in Cultural Perspective, ed. A. Appadurai. Cambridge: Cambridge University Press, 3-63.

Bloch, M. \& J. Parry, 1989. Introduction: money and the morality of exchange, in Money and the Morality of Exchange, eds. J. Parry \& M. Bloch. Cambridge: Cambridge University Press, 1-32.

Brown, H.W., 1991. Three Kilwa gold coins. Azania 26, 1-4.

Brown, H.W., 1993. Coins of East Africa: an introductory survey. Yarmouk Numismatics 5, 9-16.

Caplan, P., 1982. Gender, ideology, and modes of production 
on the Swahili Coast. Paideuma 28, 29-43.

Chami, F., 1994. The Tanzanian Coast in the First Millennium AD: an Archaeology of the Iron-working, Farming Communities. (Studies in African Archaeology 7.) Uppsala: Societas Archaeologica Upsaliensis.

Chittick, H.N., 1961. Annual Report of the Department of Antiquities. Dar es Salaam: Government Printer.

Chittick, H.N., 1965. The 'Shirazi' colonization of East Africa. Journal of African History 6, 275-94.

Chittick, H.N., 1966. Kilwa: a preliminary report. Azania $1,1-36$.

Chittick, H.N., 1973. On the chronology and coinage of the sultan of Kilwa. Numismatic Chronicle 13, 192-200.

Chittick, H.N., 1974. Kilwa: an Islamic Trading City on the East African Coast. Nairobi \& London: British Institute in Eastern Africa.

Coffin, M., 1976. Death in Early America: the History and Folklore of Customs and Superstitions of Early Medicine, Funerals, Burials and Mourning. Nashville (TN): Thomas Nelson.

Comaroff, J. \& J. Comaroff, 2006. Beasts, banknotes, and the colour of money in colonial South Africa. Archaeological Dialogues 12, 107-32.

Dalton, G., 1975. Karl Polanyi's analysis of long-distance trade and his wider paradigm, in Ancient Civilization and Trade, eds. J.A. Sabloff \& C.C. Lamberg-Karlovsky. Albuquerque (NM): University of New Mexico Press, 63-132.

Dalton, G., 1977. Aboriginal economies in stateless societies, in Exchange Systems in Prehistory, eds. T.K. Earle \& J.E. Ericson. New York (NY): Academic Press, 191-212.

Donley, L.W., 1987. Life in the Swahili town house reveals the symbolic meaning of spaces and artefact assemblages. The African Archaeological Review 5, 181-92.

Donley-Reid, L.W., 1990. The power of Swahili porcelain, beads and pottery, in Powers of Observation: Alternative Views in Archaeology, eds. S.M. Nelson \& A.B. Kehoe. (Archaeological Papers of the American Anthropological Association.) Washington (DC): American Anthropological Association, 47-59.

Eerkins, J. \& R. Bettinger, 2001. Techniques for assessing standardization in artifact assemblages: can we scale material variability? American Antiquity 66, 493-502.

Fleisher, J. \& S. Wynne-Jones, 2010a. Archaeological Investigations at Songo Mnara, Tanzania: Urban Space, Social Memory and Materiality on the 15th-and 16th-century Southern Swahili Coast. Preliminary Report submitted to the Department of Antiquities, Republic of Tanzania. Available online at: http://www.songomnara.rice. edu/results.htm

Fleisher, J. \& S. Wynne-Jones, 2010b. Kilwa-type coins from Songo Mnara, Tanzania: new finds and chronological implications. Numismatic Chronicle 170, 494-506.

Freeman-Grenville, G.S.P., 1957. Coinage in east Africa before Portuguese Times. Numismatic Chronicle 151-79.

Freeman-Grenville, G.S.P., 1958. The chronology of the Sultans of Kilwa. Tanganyika Notes and Records 50, 85-93.

Freeman-Grenville, G.S.P., 1962. The East African Coast. Select Documents from the First to the Earlier Nineteenth Centuries. London: Clarendon Press.
Godelier, M., 1999. The Enigma of the Gift. Chicago (IL): University of Chicago Press.

Gregory, C.A., 1997. Savage Money: the Anthropology and Politics of Commodity Exchange. Amsterdam: Harwood Academic Publishing.

Guyer, J., 2004. Marginal Gains: Monetary Transactions in Atlantic Africa. Chicago (IL): Chicago University Press.

Hart, K., 1986. Heads or tails? Two sides of the coin. Man 21, 637-56.

Hart, K., 2000. The Memory Bank: Money in an Unequal World. London: Profile Books.

Herbert, E.W., 1984. Red Gold of Africa: Copper in Precolonial History and Culture. Madison (WI): University of Wisconsin Press.

Hinz, W., 1955. Islamische Masse und Gewichte. Leiden: University Press.

Horton, M.C., 1996. Shanga: the Archaeology of a Muslim Trading Community on the Coast of East Africa. Nairobi: British Institute in Eastern Africa.

Horton, M.C. \& J. Middleton, 2000. The Swahili: the Social Landscape of a Mercantile Society. Oxford: Blackwell.

Horton, M.C., W.A. Oddy \& H. Brown, 1986. The Mtambwe Hoard. Azania 29, 115-23.

Huffman, T.N., 1972. An Arab coin from Zimbabwe. Arnoldia $5,1-7$.

Kilger, C., 2008. Wholeness and holiness: counting, weighing and valuing silver in the early Viking period, in Means of Exchange: Dealing with Silver in the Viking Age, ed. D. Skre. (Norske Oldfunn XXIII.) Aarhus: Aarhus University Press, 253-325.

Killick, D.J., 2009. Agency, dependency, and long-distance trade: East Africa and the Islamic world, ca. 700-1500 $\mathrm{CE}$, in Polities and Power: Archaeological Perspectives on the Landscapes of Early States, eds. S.E. Falconer \& C.L. Redman. Tucson (AZ): University of Arizona Press.

Kus, S.M. \& V. Raharijaona, 2008. 'Desires of the heart' and laws of the marketplace: money and poetics, past and present, in highland Madagascar, in Dimensions of Ritual Economy, eds. E.C. Wells \& P.A. McAnany. (Research in Economic Anthropology 27.) Bingley: JAI Press, 149-85.

Kus, S.M. \& V. Raharijaona, forthcoming. Small change in Madagascar: sacred coins and profaned coinage, in The Archaeology of Politics: the Materiality of Political Practice and Action in the Past, eds. P. Johansen \& A. Bauer. Newcastle: Cambridge Scholars Press.

Kusimba, C.M., 1999. Material symbols among the precolonial Swahili of the East African coast, in Material Symbols: Culture and Economy in Prehistory, ed. J.E. Robb. (Center for Archeological Investigations Occasional Paper 26.) Carbondale (IL): Southern Illinois University, 318-41.

Lambek, M., 2001. The value of coins in a Sakalava polity: money, death and historicity in Mahajanga, Madagascar. Comparative Studies in Society and History 43, 735-62.

LaViolette, A., 2008. Swahili cosmopolitanism in Africa and the Indian Ocean world, AD 600-1500. Archaeologies: Journal of the World Archaeological Congress 1, 24-49.

Lowick, N., 1990. Coinage and History of the Islamic World. 
London: Variorum Publishing.

Malinowski, B., 1922. Argonauts of the Western Pacific. London: Routledge \& Kegan Paul.

Mathew, G., 1959. Songo Mnara. Tanganyika Notes and Records 53, 154-60.

Maurer, B., 2005. Does money matter? Abstraction and substitution in alternative financial forms, in Materiality, ed. D. Miller. Durham (NC): Duke University Press, 140-64.

Maurer, B., 2006. The anthropology of money. Annual Review of Anthropology 35, 15-36.

Mauss, M., 2002 [1954]. The Gift: the Form and Reason for Exchange in Archaic Societies. London \& New York (NY): Routledge.

Middleton, J., 2003. Merchants: an essay in historiographical ethnography. Journal of the Royal Anthropological Institute 9, 509-26.

Miller, D. \& C. Tilley, 1984. Ideology, power and prehistory, in Ideology, Power and Prehistory, eds. D. Miller \& C. Tilley. Cambridge: Cambridge University Press, 1-16.

Mitchell, H., 1970. Fakhr al-Dunya and Nasir al-Dunya: notes on two East African topics. Numismatic Chronicle $10,253-7$.

Munn, N.D., 1986. The Fame of Gawa: a Symbolic Study of Value Transformation in a Massim (Papua New Guinea) Society. Cambridge: Cambridge University Press.

Ogundiran, A., 2002. Of small things remembered: beads, cowries, and cultural translations of the Atlantic experience in Yorubaland. International Journal of African Historical Studies 35, 427-57.

Pallaver, K., 2009. 'A recognized currency in beads'. Glass beads as money in 19th-century East Africa: the central caravan road, in Money in Africa, eds. C. Eagleton, H. Fuller \& J. Perkins. London: British Museum Press, 20-29.

Palmer, C., 1998. From theory to practice: experiencing the nation in everyday life. Journal of Material Culture 3, 175-99.

Perry, W. \& J. Woodruff, 2006. Coins, shells, pipes and other items, in New York African Burial Ground: Archaeology Final Report, eds. W. Perry, J. Howson \& B. Bianco. Washington (DC): Howard University, 419-43.

Polanyi, K., 1957. The economy as instituted process, in Trade and Markets in the Early Empires: Economies in History and Theory, eds. K. Polanyi, C.M. Arensberg \& H.W. Pearson. New York (NY): Free Press, 243-70.

Polanyi, K., 1968. Primitive, Archaic and Modern Economies. Essays of Karl Polanyi. Boston (MA): Beacon Press.

Pradines, S. \& P. Blanchard, 2005. Kilwa al-Mulûk. Premier bilan des travaux de conservation-restauration et des fouilles archéologiques dans la baie de Kilwa, Tanzanie. Annales Islamologiques 39, 25-80.

Prestholdt, J., 1998. As Artistry Permits and Custom May Ordain: the Social Fabric of Material Consumption in the Swahili World, circa 1450 to 1600. (PAS Working Papers 3.) Evanston (IL): Program of African Studies, Northwestern University.

Spufford, P., 1988. Money and its Use in Medieval Europe. Cambridge: Cambridge University Press.
Stiansen, E. \& J. Guyer (eds.), 1999. Credit, Currencies, and Culture: African Financial Institutions in Historical Perspective. Stockholm: Nordiska Afrikainstitutet.

Strathern, M., 1992. Qualified value: the perspective of gift exchange, in Barter, Exchange and Value: an Anthropological Approach, eds. C. Humphrey \& S. Hugh-Jones. Cambridge: Cambridge University Press, 169-91.

Sutton, J.E.G., 1998. Kilwa: a history of the ancient Swahili town with a guide to the monuments of Kilwa Kisiwani and adjacent islands. Azania 33, 113-69.

Theuws, F., 2004. Exchange, religion, identity and central places in the early Middle Ages. Archaeological Dialogues 10, 121-38.

Thomas, N., 1991. Entangled Objects: Exchange, Material Culture, and Colonialism in the Pacific. Cambridge (MA): Harvard University Press.

Thompson, R.F., 1983. Flash of the Spirit: African and AfroAmerican Art and Philosophy. New York (NY): Vintage Books.

Verin, P., 1986. The History of Civilization in North Madagascar, trans. D. Smith. Rotterdam and Boston: Balkema.

Walker, J., 1936. The history and coinage of the sultans of Kilwa. Numismatic Chronicle 16, 43-81.

Walker, J., 1939. Some new coins from Kilwa. Numismatic Chronicle 19, 223-7.

Walker, J. \& G.S.P. Freeman-Grenville, 1956. The history and coinage of the sultans of Kilwa. Tanganyika Notes and Records 45, 33-65.

Watters, D., 1994. Mortuary patterns at the Harney site slave cemetery, Montserrat, in Caribbean perspective. Historical Archaeology 28(3), 56-73.

Weiner, A.B., 1992. Inalienable Possessions: the Paradox of Keeping-While-Giving. Berkeley (CA): University of California Press.

Williams, J., J. Cribb \& E. Errington, 1997. Money: a History. London: British Museum Press.

Wynne-Jones, S. \& J.B. Fleisher, 2010. Archaeological investigations at Songo Mnara, Tanzania, 2009. Nyame Akuma 73, 2-8.

\section{Author biographies}

Stephanie Wynne-Jones (PhD 2005, University of Cambridge) is a Lecturer in the Department of Archaeology, University of York. Her research focuses on material culture, and particularly on the relationship between objects, identities, and society. Her current project at Songo Mnara revolves around the archaeology of households and the links between spaces, activities and artefacts. These interests are pursued in the archaeology of East Africa, and particularly on the Swahili coast.

Jeffrey Fleisher (PhD 2003, University of Virginia) is an Assistant Professor at Rice University. His research interests are on the ephemeral parts of ancient urban societies, including rural and non-elite people as well as open and public space. Focused on ancient Swahili sites, his research addresses issues of political economy, consumption, social memory and ritual. 